\title{
A THREE-FACTOR AGRICULTURAL PRODUCTION FUNCTION: THE CASE OF CANADA*
}

\author{
Cristina Echevarría*
}

WP-AD 97-12

\author{
Correspondence to: Cristina Echevarria \\ Department of Economics \\ University of Saskatchevan \\ 9 Campus Drive \\ Saskatoon, SK \\ S7N 5AS Canada \\ E-mail: echevarr@duke.usak.ca
}

Editor: Instituto Valenciano de Investigaciones Económicas, S.A.

First Edition April 1997

ISBN: 84-482-1481-1

Depósito Legal: V-1348-1997

IVIE working-papers offer in advance the results of economic research under way in order to encourage a discussion process before sending them to scientific journals for their final publication.

"I thank Will Martin for comments on a previous paper which lead to this work; Ray Bollman, Hartley Furtan, and Ken Rosaasen for their help with Canadian agriculture data; an anonymous referee, Antonia Díaz and the participants at the Seminar of the Department of Economics of the University of Saskatchewan for their comments and suggestions. This paper was completed when I was visiting the Universidad de Alicante. Support from the Instituto Valenciano de Investigaciones Económicas, the Dirección General de Enseñanza Superior and the University of Saskatchewan (start-up research grant) is gratefully acknowledge.

${ }^{* *}$ C. Echevarria: University of Saskatchewan and University of Alicante. 


\title{
A THREE-FACTOR AGRICULTURAL PRODUCTION FUNCTION: THE CASE OF CANADA
}

\author{
Cristina Echevarría
}

\begin{abstract}
A B S T R A C T
This paper estimates a constant returns to scale agricultural production function with just three inputs: land, labour and capital -the basic factors of production. It uses the shares approach that Solow used in 1957 and very disaggregated Canadian data. A constant returns to scale function of the three basic factors of production is a useful tool for macroeconomic, and growth and development studies. The main results of this paper are that, first, in Canada agriculture is less labour intensive than both services and industry, but capital intensity is similar in the three sectors. Second, the share of land in value added is estimated to be $16 \%$ Third, total factor productivity growth in Canada has been roughly the same -0'3\%- in agriculture and manufactures over the period 1971-91.
\end{abstract}

KEYWORDS: Constant Returns to Scale; Land; Total Factor Productivity Growth. 